\title{
Spatial and Temporal Variation in Evapotranspiration
}

\author{
Jerry L. Hatfield and John H. Prueger \\ National Laboratory for Agriculture and the Environment \\ United States of America
}

\section{Introduction}

Evapotranspiration represents the combined loss of soil water from the earth's surface to the atmosphere through evaporation of water from the soil or plant surfaces and transpiration via stomates of the plant. In agricultural production systems these two losses of water represent a major component of the water balance of the crop. If we examine evapotranspiration over time throughout a growing season of a crop then the fractions of evaporation and transpiration will not remain constant. When there is a small plant partially covering the soil then the energy impinging on the soil surface will be used to evaporate water from the soil surface; however, as the crop develops and completely covers the soil then transpiration becomes the dominant process. There is a spatial and temporal aspect to evapotranspiration which exists but is often ignored in our consideration of the dynamics of water loss from the earth's surface.

One of the major questions which exists is how uniform is evapotranspiration over a given production field or over a landscape because of the limited amount of information on the spatial variation of evapotranspiration. There have been a limited number of research studies on the spatial variation in evapotranspiration. Many of these studies utilize remote sensing data as shown by Zhang et al. (2010) in which they developed a spatial-temporal evapotranspiration model for the Hebei Plain in China. They found the temporal variation in evapotranspiration was due to crop growth and the irrigation regime while spatial variation was caused by the type of crop being grown. An aspect of evapotranspiration is the use of reference pan evaporation to provide a surrogate for the atmospheric evaporation and the results from a study by Zhang et al. (2009) showed spatial variation was induced by changes in the driving variables, e.g., windspeed, solar radiation, or temperature. Variations in these parameters would be expected to create spatial differences in evapotranspiration from crop surfaces. Spatial and temporal variation in crop reference evapotranspiration has been studied by Zhang et al. (2010) across a river basin in China and observed the spatial variation in reference evapotranspiration was low in the cool months (January to April) and large in the warm months (May to August). The driving variable inducing the spatial variation in the warm months was most closely related to variation in the available energy among locations.

$\mathrm{Li}$ et al. (2006) evaluated the combination of remote sensing data combined with surface energy balance to evaluate the spatial variation in evapotranspiration and found the mean values of evapotranspiration were similar across a range of spatial scales. However, the 
standard deviation decreased with higher spatial resolution and when the increased above $480 \mathrm{~m}$, there was a loss of spatial structure in the evapotranspiration maps. Using a Raman lidar system, Eichinger et al. (2006) observed large spatial variation in evapotranspiration in corn (Zea mays L.) and soybean (Glycine max (L.) Merr.) linked with small elevation differences within the fields. These observations would suggest spatial structure has different scales and there are few studies which have attempted to evaluate spatial variation and the underlying causes. Mo et al. (2004) used a simulation model to evaluate evapotranspiration and found spatial variation was closely related to spatial patterns in precipitation and leaf area of the crop. This is similar to observations by Hatfield et al. (2007) from an experiment in central Iowa in which they observed that spatial variation in energy and carbon fluxes among different corn and soybean fields could be attributed to three factors. These factors were presence of cumulus clouds in the afternoon, variation in precipitation amounts across a watershed, and differences in the soil water availability in the soil profile. These studies demonstrate that there is spatial and temporal variation present in evapotranspiration from agricultural surfaces.

Evapotranspiration is a process controlled by the available energy, gradient of water vapor, availability of water for evaporation, and the gradient of windspeed as the transport process. The linkages among these parameters can be more easily seen in an expanded mathematical description of the latent heat flux $(\lambda \mathrm{E})$ given as

$$
\lambda E=\frac{(\rho \lambda m / P)\left(e_{s}-e_{a}\right)}{\left(r_{c}+r_{a v}\right)}
$$

where $\lambda$ is the latent heat of vaporization $\left(\mathrm{J} \mathrm{kg}^{-1}\right), \rho$ the density of air $\left(\mathrm{kg} \mathrm{m}^{-3}\right), \mathrm{m}$ the ratio of molecular weight of water vapor to than of air $(0.622), P$ the barometric pressure $(\mathrm{kPa}), \mathrm{e}_{\mathrm{s}}$ the saturation vapor pressure, $\mathrm{e}_{\mathrm{a}}$ the actual vapor pressure of the air immediately above the surface, $r_{c}$ the canopy resistance for water vapor transfer $\left(\mathrm{s} \mathrm{m}^{-1}\right)$, and $r_{a v}$ the aerodynamic resistance for water vapor transfer $\left(\mathrm{s} \mathrm{m}^{-1}\right)$. There has been much written about the linkages among these parameters; however, for a surface, evapotranspiration must be placed in context of the surface energy balance so that the balance of energy is expressed as

$$
R_{n}-G-H=\lambda E
$$

where $R_{n}$ is the net radiation at the surface $\left(\mathrm{J} \mathrm{m}^{-2} \mathrm{~s}^{-1}\right), \mathrm{G}$ the soil heat flux $\left(\mathrm{J} \mathrm{m}^{-2} \mathrm{~s}^{-1}\right)$, and $\mathrm{H}$ the sensible heat flux $\left(\mathrm{J} \mathrm{m}^{-2} \mathrm{~s}^{-1}\right)$. It is the combination of the various factors which gives rise to the potential spatial and temporal variation in evapotranspiration. For example, the annual variation in solar radiation causes the amount of energy available for evapotranspiration to vary in a predictable way throughout the year. Farmer et al. (2003) found that climate and landscape were the two critical affecting the soil water balance. Kustas and Albertson (2003) observed spatial variation across the landscapes and proposed that our understanding of the critical knowledge gaps affecting spatial and temporal variation in evapotranspiration is lacking.

Measurements of energy balance components and estimates of evapotranspiration from Eq. 1 or 2 are often conducted over a single site within a production field or a landscape. The assumption from this measurement is that these values represent that particular surface with sufficient accuracy from which we derive an understanding of the dynamics of the surface. There are few studies in the literature which have directly measured evapotranspiration within a field to quantify the spatial variation and the factors which 
create variation. The studies mentioned above have used remote sensing imagery as a surrogate for the energy balance and their results show there is spatial variation at relatively small scales; however, these scales are still often larger than areas within a production field. We have been addressing the problem of quantifying the spatial and temporal variation in evapotranspiration through a series of related studies across corn and soybean fields in central Iowa. These studies provide us insights into how crop management interacts with the landscape to induce variation in evapotranspiration.

\section{Methodological approach}

\subsection{Energy balance measurements}

The experimental site for these studies is located in central Iowa in a production field typical of the area on large (30-35 ha) fields located at $41.967^{\circ} \mathrm{N}, 93.695^{\circ} \mathrm{W}$ on a Clarion-NicolletWebster Soil Association using micrometeorological measurements of $\mathrm{H}_{2} \mathrm{O}$ vapor and $\mathrm{CO}_{2}$ exchanges above the canopy using an energy approach described by Hatfield et al., (2007). The energy balance approach used in these studies combines fast response of $\mathrm{CO}_{2}$ and $\mathrm{H}_{2} \mathrm{O}$ vapor signals with sonic anemometers, net radiation components, soil heat flux, and surface temperature. The use of this approach requires a large area to meet the fetch requirements and data have been collected at this site since 1998 where the data capture rate for these systems is greater than 95\% (Hernandez-Ramirez et al., 2009).

Turbulent fluxes of sensible and latent heat $(\mathrm{H} \& \mathrm{LE})$ and $\mathrm{CO}_{2}$ were measured using the eddy covariance (EC). Each EC system is comprised of a three-dimensional sonic anemometer (CSAT3 Campbell Scientific Inc. Logan, UT ${ }^{1}$ ) and a fast response water vapor $\left(\mathrm{H}_{2} \mathrm{O}\right)$ and $\mathrm{CO}_{2}$ density open path infrared gas analyzer (IRGA) (LI7500 LICOR Inc., Lincoln, $\mathrm{NE}$ ). In both the corn and soybean fields, EC instrument height is maintained on the $10 \mathrm{~m}$ towers at approximately $2 \mathrm{~h}$ (where $\mathrm{h}=$ canopy height in $\mathrm{m}$ ) above the surface. The sampling frequency for the EC systems was $20 \mathrm{~Hz}$ with all of the high frequency data directly transmitted to the laboratory.

Ancillary instrumentation on each tower includes a 4-component net radiometer $\left(R_{n}\right)(C N R-$ 1 Kipp \& Zonen Inc., Saskatoon, Sask.), soil heat flux plates (G) (REBS HFT-3) Cu-Co Type T soil thermocouples, two high precision infrared radiometric temperature sensors (IRT $15^{\circ}$ fov) (Apogee Instruments Inc., Logan, UT) and an air temperature/ relative humidity $\left(\mathrm{T}_{\mathrm{a}}\right)$ (RH) sensor (Vaisala HMP-35, Campbell Scientific Inc. Logan UT). The $R_{n}$ air temperature/humidity and one IRT ( $45^{\circ}$ angle of view) sensor are mounted $4.5 \mathrm{~m}$ above ground level (AGL). The second IRT sensor is located $0.15 \mathrm{~m}$ AGL with a nadir view providing continuous radiometric temperatures of the soil surface. Four soil heat flux plates are placed $0.06 \mathrm{~m}$ below the soil, two within the plant row and two within the inter-row space. Pairs of soil thermocouples are placed 0.02 and $0.04 \mathrm{~m}$ below the surface and above each soil heat flux plate. Soil water content in the top $0.1 \mathrm{~m}$ at each site will be measured with Delta-T Theta Probes (Dynamax Houston TX) and together with soil temperature data used to compute the storage component of the soil heat flux. The sampling frequency for the ancillary instrumentation is $0.1 \mathrm{~Hz}(10 \mathrm{~s})$ with measured values stored as $10 \mathrm{~min}$ averages.

\subsection{Field scale studies}

To evaluate the impact of management on evapotranspiration, production sized fields have been used as experimental units because of the need to quantify the effects of $\mathrm{N}$ management on crop growth and yield and water use across a series of soil types. Fields 
range in size from 32 to 96 ha and are located in the Clarion-Nicollet-Webster Soil Association in central Iowa within the Walnut Creek watershed. This 5,400 ha watershed has been used for extensive research on environmental quality in relation to farming practices as described by Hatfield et al. (1999). Nitrogen management practices have varied across each year in response to the observations obtained from these experiments. The goal of these experiments has been to quantify the interactions of water and $\mathrm{N}$ across soil types with different $\mathrm{N}$ management practices. The most intensive studies have been conducted within a 60 ha field divided into two fields in a corn-soybean rotation with the primary emphasis on the corn portion of the rotation. The corn hybrid grown in these studies was Pioneer $33 \mathrm{P} 671$ for the duration of the study. The management practices placed different $\mathrm{N}$ rates in the field in large strips of 10 ha so the field was divided into no more than three strips in any one year. Within the field plant sampling, energy balance and crop yield plots were located within a given soil type. In this field, the predominant soils are Clarion, Canisteo, and Webster soils. Within each soil type and $\mathrm{N}$ management practice a plot area were identified and marked with GPS coordinates in order to locate the exact area among growing seasons.

Nitrogen management practices have been similar from 1997 through 2001. Nitrogen rates applied in 1997 and 1998 using a starter application at planting of $56 \mathrm{~kg}^{\mathrm{ha}}{ }^{-1}$ only with the second treatment having the $\mathrm{N}$ starter rate and the sidedress rate determined by the Late Spring Nitrate Test (LSNT). The third treatment was the starter plus a rate to represent a non-limiting $\mathrm{N}$ rate of an additional $168 \mathrm{~kg} \mathrm{ha}^{-1}$. In 1999, 2000, and $2001 \mathrm{~N}$ application was modified to further refine rates based on leaf chlorophyll measurements and soil tests obtained from the 1997 and 1998 experiments. The rates applied were 56, 112, 168, or $232 \mathrm{~kg}$ $\mathrm{N} \mathrm{ha}^{-1}$ to different soils, planting rates, and plant population densities $(75,000$ and 85,000 plants ha-1). In 2000 and 2001, $\mathrm{N}$ was applied as either anhydrous ammonia in the fall or liquid urea anhydrous (UAN) in the spring at planting with a sidedress application. These applications were applied with production scale equipment to the field. Soil $\mathrm{N}$ concentrations were measured prior to spring operations, after planting, and at the end of the growing season after harvest to a soil depth of $1.5 \mathrm{~m}$ using a $5 \mathrm{~cm}$ core. Cores were subdivided into depth increments to estimate the $\mathrm{N}$ availability throughout the root zone at each of the sampling times. Sample position was recorded with a GPS unit to ensure accurate location of each subsequent sample.

\subsection{Watershed scale studies}

A watershed scale was conducted in the Walnut Creek Watershed in central Iowa located 5 $\mathrm{km}$ south of Ames, Iowa $\left(41^{\circ} 75^{\prime} \mathrm{N}, 93^{\circ} 41^{\prime} \mathrm{W}\right)$ as part of an ongoing long-term monitoring effort to assess interactions of crop water use, $\mathrm{CO}_{2}$ uptake, and yield as a function of nitrogen management for corn and soybeans. Walnut Creek Watershed is a 5100 ha watershed of intensive corn and soybean production fields ranging in size from 40-160 ha. These two crops occupy approximately $85 \%$ of the land area in the watershed. The topography of the watershed and surrounding areas are characterized by flat to gently rolling terrain with elevations in the watershed ranging from $265-363 \mathrm{~m}$ with the lowest elevations situated on the eastern end of the watershed where the Walnut Creek drains. Details of production, tillage and nutrient management systems within the watershed are described in Hatfield et al. (1999).

\footnotetext{
${ }^{1}$ Mention of trade names or commercial products in this article is solely for the purpose of providing specific information and does not imply recommendation or endorsement by the U.S. Department of Agriculture.
} 
To most extensive and intensive experiment was conducted in 2002 as part of a remote sensing soil moisture experiment (SMEX02) being was conducted across the Walnut Creek Watershed. This study provided the opportunity to place 12 eddy covariance (EC) stations across the watershed to measure and evaluate the spatial and temporal variation among fluxes across typical corn and soybean production fields in the Upper Midwest region. These stations were in operation during the intensive measurement period of the remote sensing campaign (Kustas et al., 2003) and continued to record measurements until late August 2002. These sites were distributed across the Walnut Creek watershed as shown in Fig 1 and sites 10 and 11 represent in the intensive field sites for the experiments conducted since 1998 on combinations of nitrogen management and water across soils types described above. For each site in the field the soil type was extracted from the soil map from Boone or Story County, Iowa. Eddy covariance sites were located in a range of soil types typical of central Iowa and in most fields the location represented over 0.20 of the total area in the field. The primary difference among the soils was the soil water holding capacity in the upper $1 \mathrm{~m}$ of the soil profile (Table 1). This provided an excellent opportunity to not only measure and evaluate differences in turbulent fluxes between corn and soybeans but also the spatial and temporal variability of turbulent flux exchange of $\mathrm{CO}_{2}$ and $\mathrm{H}_{2} \mathrm{O}$ across the agricultural landscape. The full details of the SMCAEX study are described in Kustas et al. (2005).

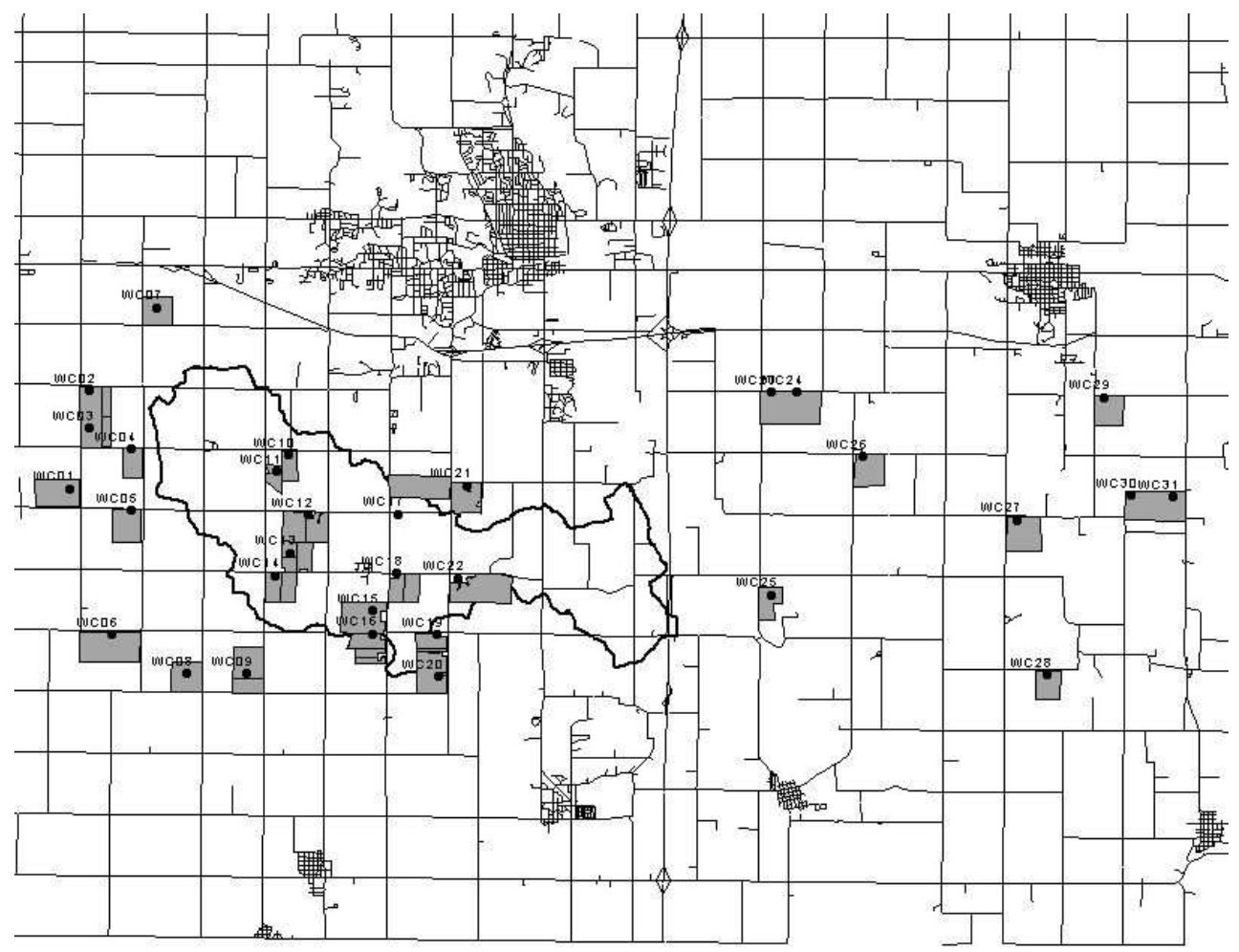

Fig. 1. Distribution of the energy balance and evapotranspiration measurement sites across Walnut Creek watershed in 2002. 


\begin{tabular}{|c|c|c|c|c|}
\hline Site & Crop & Soil Type & $\begin{array}{l}\text { Fraction of } \\
\quad \text { Field }\end{array}$ & $\begin{array}{l}\text { Soil Water Holding } \\
\text { Capacity } \\
(\mathrm{mm} \text { for upper } 1 \mathrm{~m})\end{array}$ \\
\hline 3 & Soybean & $\begin{array}{l}\text { Clarion, fine-loamy, mixed, mesic } \\
\text { Typic Hapludolls }\end{array}$ & 0.30 & 212 \\
\hline 6 & Corn & $\begin{array}{l}\text { Clarion, fine-loamy, mixed, mesic } \\
\text { Typic Hapludolls }\end{array}$ & 0.24 & 212 \\
\hline 10 & Corn & $\begin{array}{c}\text { Nicollet, Fine-loamy, mixed, mesic } \\
\text { Aquic Hapludolls }\end{array}$ & 0.16 & 220 \\
\hline 11 & Soybean & $\begin{array}{c}\text { Harps, Fine-loamy, mesic Typic } \\
\text { Calciaquolls }\end{array}$ & 0.18 & 221 \\
\hline 13 & Soybean & $\begin{array}{l}\text { Harps, Fine-loamy, mesic Typic } \\
\text { Calciaquolls }\end{array}$ & 0.12 & 221 \\
\hline 14 & Soybean & $\begin{array}{l}\text { Clarion, fine-loamy, mixed, mesic } \\
\text { Typic Hapludolls }\end{array}$ & 0.24 & 212 \\
\hline 25 & Corn & $\begin{array}{l}\text { Spillville, Fine-loamy, mixed, } \\
\text { mesic Cumulic Hapludolls }\end{array}$ & 0.41 & 214 \\
\hline 33 & Corn & $\begin{array}{c}\text { Nicollet, Fine-loamy, mixed, mesic } \\
\text { Aquic Hapludolls }\end{array}$ & 0.10 & 220 \\
\hline 151 & Corn & $\begin{array}{c}\text { Clarion, fine-loamy, mixed, mesic } \\
\text { Typic Hapludolls }\end{array}$ & 0.34 & 212 \\
\hline 152 & Corn & $\begin{array}{c}\text { Canisteo, Fine-loamy, mixed } \\
\text { (calcareous), mesic Typic } \\
\text { Haplaquolls }\end{array}$ & 0.33 & 209 \\
\hline 161 & Soybean & $\begin{array}{l}\text { Clarion, fine-loamy, mixed, mesic } \\
\text { Typic Hapludolls }\end{array}$ & 0.35 & 212 \\
\hline 162 & Soybean & $\begin{array}{l}\text { Clarion, fine-loamy, mixed, mesic } \\
\text { Typic Hapludolls }\end{array}$ & 0.35 & 212 \\
\hline
\end{tabular}

Table 1.

\section{Observations across scales}

\subsection{Temporal variation among years}

Variation among years for evapotranspiration in rainfed areas is dependent upon the amount of precipitation stored within the soil profile. If there is adequate storage capacity, then annual variation in evapotranspiration will more dependent upon the available energy than upon the amount of available water. In areas with soils with limited soil water holding capacity then a more direct relationship will be evident. Across central Iowa, which would be typical of the Corn Belt, there is large annual variation in evapotranspiration as evidenced in the data from 1998 (Fig.2), 1999 (Fig. 3), and 2000 (Fig. 4).

Two important details are evident from these three years which represent fairly typical years in central Iowa. First, there is little evapotranspiration occurring the winter months and fall as evidenced by the relatively small cumulative values during these intervals. Evapotranspiration does not begin to become significant portion of the energy balance (Eq. 2) until about DOY 100 and begins to diminish after DOY 300 (Figs. 2, 3 and 4). These seasonal patterns are consistent among years with very similar times in which evapotranspiration values begin to increase in 
the spring and decrease in the fall. Second, cumulative values of evapotranspiration are relatively smooth compared to precipitation values, which occur in infrequent storms, not every day, and throughout the year. Third, annual total values of evapotranspiration are more similar among years than are annual precipitation totals. As an example, total evapotranspiration for 1998 was $476 \mathrm{~mm}, 1999-500 \mathrm{~mm}$, and $2000-433 \mathrm{~mm}$ while total precipitation for 1998 was 933, for $1999-743$, and for $2000-454 \mathrm{~mm}$. Temporal variation in evapotranspiration among years will be dependent upon the energy available and at the annual time scale there are minor differences among years.

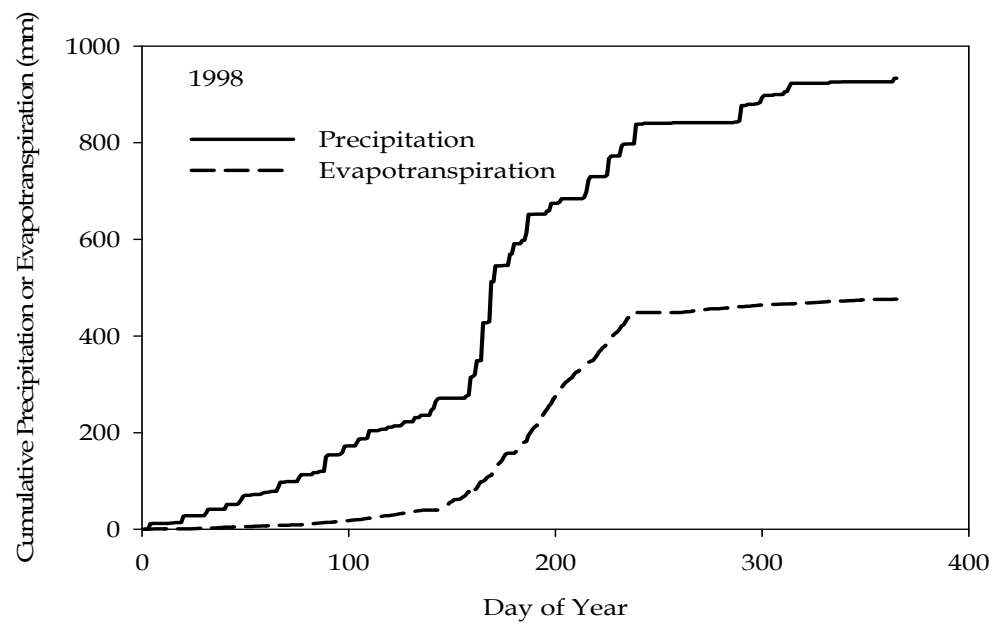

Fig. 2. Annual cumulative precipitation and evapotranspiration for a corn production field for Central Iowa in 1998.

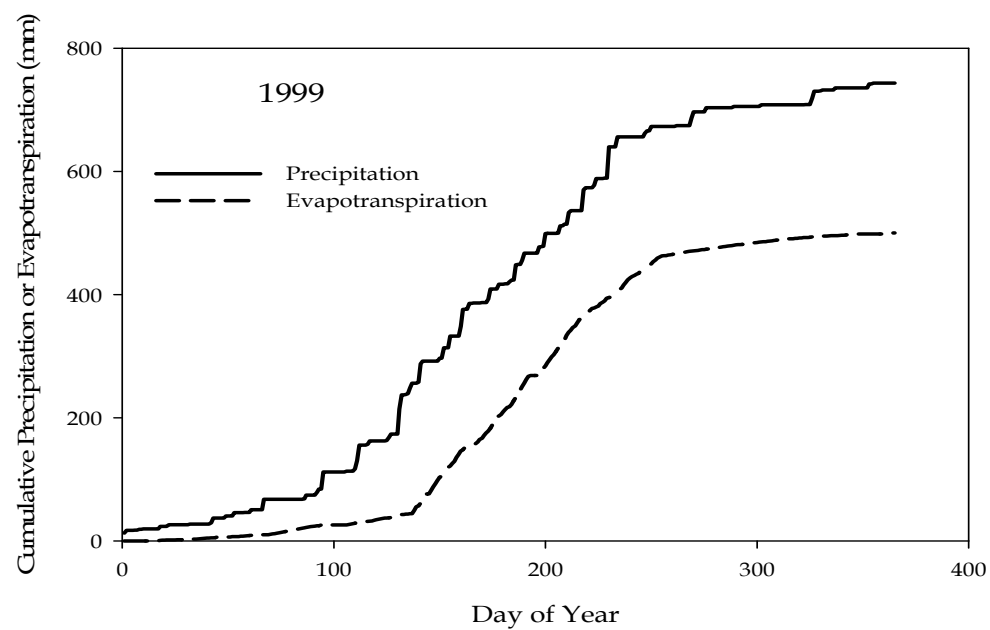

Fig. 3. Annual cumulative precipitation and evapotranspiration for a corn production field for Central Iowa in 1999. 


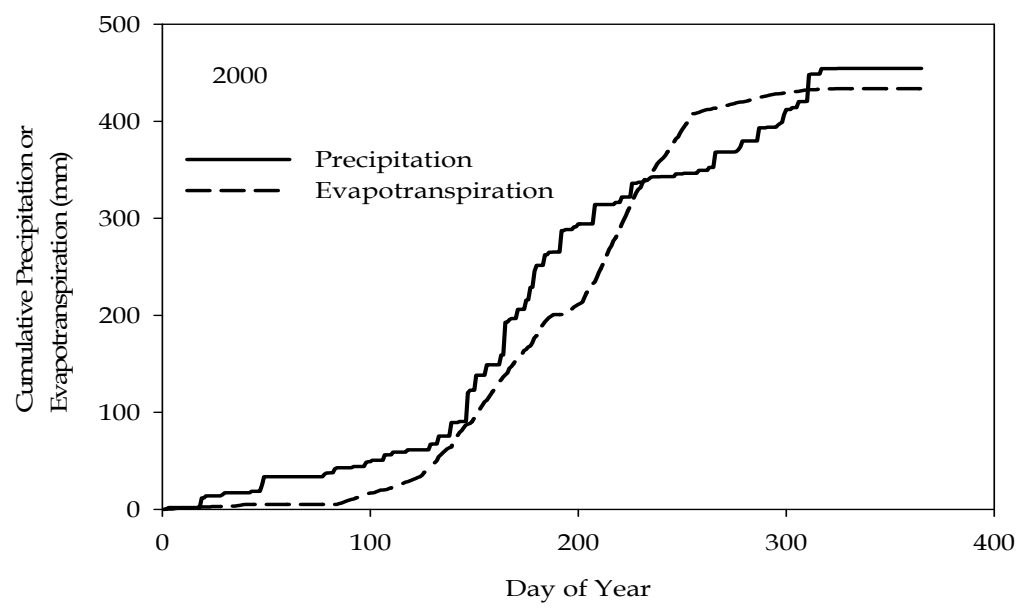

Fig. 4. Annual cumulative precipitation and evapotranspiration for a corn production field for Central Iowa in 2000.

\subsection{Spatial variation within production fields}

Spatial variation of evapotranspiration within fields is more significant than often thought based on the results shown in Figs 2, 3, and 4. It is assumed that evapotranspiration across a field would be relatively consistent because the energy balance components would be consistent. We have examined this aspect across both corn and soybean fields and found there is a large spatial variation induced by soil water holding capacity. An example of this variation is shown in Fig. 5 for evapotranspiration from a corn crop in an Okoboji soil compared to a Clarion soil and a Nicollet soil. The Okoboji soil is a high organic matter soil (soil organic matter of 7-9\%) compared to a Nicollet soil (soil organic matter of 3-5\%) and a Clarion soil (soil organic matter of 1-2\%). These soils represent three different positions on the landscape with the Clarion soil being the upper part of the landscape in the ClarionNicollet-Webster soil association while the Okoboji soils are the lower part of the landscape and often considered to be poorly drained soils while the Nicollet soil is about midway on the slope.

There are large differences in the seasonal totals among these three soils (Fig. 5). The seasonal totals for the Okoboji and Nicollet soils are quite similar at 575 and $522 \mathrm{~mm}$, respectively while the Clarion soil has an annual total of $310 \mathrm{~mm}$. There are differences among the patterns of evapotranspiration throughout the year for the three soils. These types of patterns are not uncommon based on our multiple years of measurements across this field in which we have measured evapotranspiration in different soils. In this field, the evapotranspiration from the Okoboji soil begins slower at the beginning of the season because the tillage practice leaves this area with crop residue which decreases soil water evaporation rates and also the plant growth tends to be slower in this area of the field. In the Nicollet soils, there is more soil water evaporation and earlier plant growth because these areas of the field show an increased rate of growth because of the more favorable growth conditions. In contrast, the Clarion soils behave similar to the Nicollet soils in the early season but then at as the crop grows there is insufficient soil water to maintain the water 
supply and evapotranspiration becomes limited. This is a common occurrence in these fields and we often observe evapotranspiration totals in the Clarion soils at least half of the soils with the higher water holding capacity. These areas of the field also exhibit water deficits throughout the growing season because the soil is unable to supply the water required to meet the atmospheric demand and the canopy resistance term (Eq. 1) is much higher in these plants than in other soils within the field. There is a spatial variation of evapotranspiration within a field induced by the soil water holding capacity and this will influence the ability of the plant to be able to extract water to meet atmospheric demand.

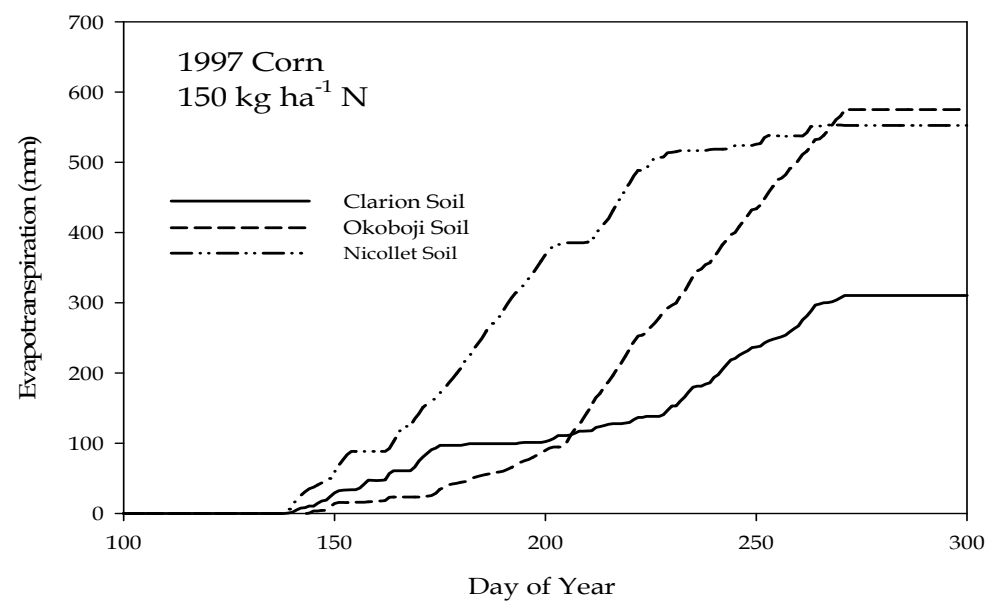

Fig. 5. Seasonal cumulative evapotranspiration from a corn crop grown in an Okoboji and Clarion soil within an individual field during 1997.

Spatial variation of evapotranspiration within a field can be affected by the effect of soil management practices on the crop growth patterns. We have investigated the interactions of nitrogen management with evapotranspiration across production fields. These seasonal totals are confined to the growing season because of the minimal amount of evapotranspiration during the other times of the year as shown in the earlier section. Nitrogen management interacted with soil type in the seasonal evapotranspiration totals reflective of the effect of nitrogen on growth in the different soils. In this study, we compared water use and crop growth in a Webster and Clarion soil. The Webster soil is similar to the Nicollet soil with soil organic matter contents of 3-5\%. In this study, the seasonal evapotranspiration totals for both the fall and spring nitrogen application rates showed differences among soils with the Clarion soil having less evapotranspiration than the Webster soils (Fig. 6). There is an interesting effect of nitrogen application rates in this study because the application of $200 \mathrm{~kg} \mathrm{ha}^{-1}$ on the Clarion soil actually reduced evapotranspiration compared to the $100 \mathrm{~kg} \mathrm{ha}^{-1}$ rate (Fig. 6). We have observed this response in different years because the low water holding capacity soils cannot supply adequate water for evapotranspiration and there is actually a reduction in plant growth from the excess nitrogen applied. The reverse effect is found in the Webster soil where there is no 
difference in evapotranspiration rates until late in the growing season when the additional nitrogen from the $200 \mathrm{~kg} \mathrm{ha}^{-1}$ rate is able to sustain growth and maintain evapotranspiration rates compared to the $100 \mathrm{~kg} \mathrm{ha}^{-1}$ rate (Fig. 6).

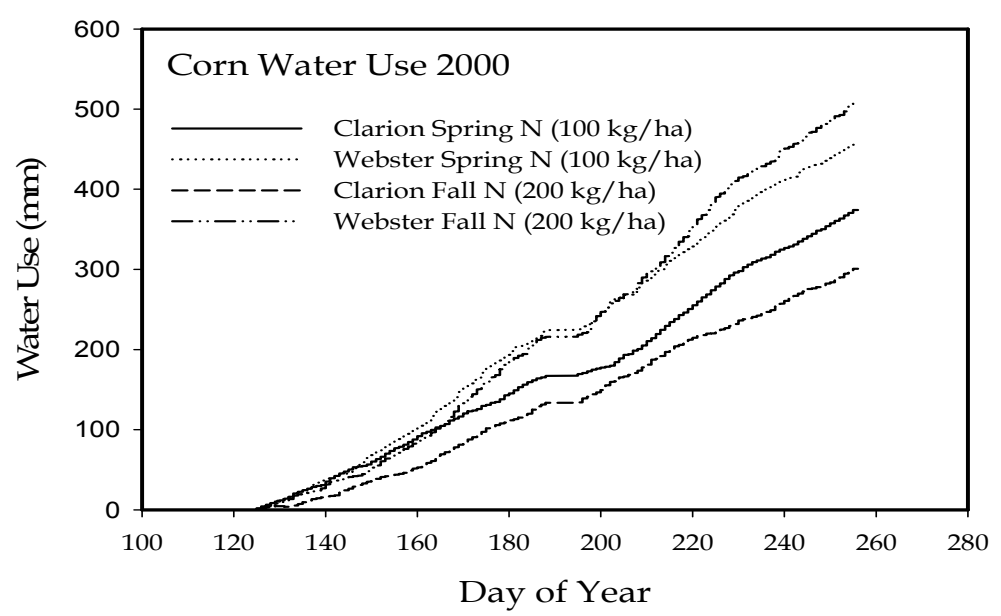

Fig. 6. Seasonal cumulative evapotranspiration values for corn in central Iowa from two different soils in 2000 with different nitrogen rates and application times.

Spatial variation patterns within a field have often been assumed to be minimal; however, these differences are larger than expected because of the differences in soil water holding capacity. The seasonal evapotranspiration patterns represent the combined effects of soils and management and these differences will affect the ability of a crop to endure water stress during the growing season. In rainfed environments, it is critical for precipitation events to maintain the soil water supply at an optimum level and if there is a limitation in the ability of the soil to store water and meet the evapotranspiration rate then crops will undergo water deficit stress.

\subsection{Spatial variation among production fields}

There have been few studies which have attempted to quantify the differences in evapotranspiration rates among fields. The primary reason is the expense of the array of equipment and the labor requirements to establish this observational network. As part of the SMEX2002 experiment described by Kustas et al. (2003) we were able to establish a network of energy balance stations and eddy correlation equipment across Walnut Creek watershed in central Iowa as shown in Fig. 1. The details of the study have been reported by Hatfield et al. (2007) and they observed variability among fields was due to three factors. Within a day, differences in the energy balance components and evapotranspiration was caused by the presence of cumulus clouds. Clouds are not evenly distributed across the watershed and differentially shade one area of the watershed more than another. These effects do not persist from one day to the next because the presence of clouds over a given field changes among days. However, these effects do induce evapotranspiration differences among fields. 
The second factor which caused differences among fields was the spatial variation in precipitation events across the watershed. In temperate climates it is not unusual for convective rainfall amounts to be variable across space and this changes the amount of water available for evaporation. The scale of differences induced by variable precipitation is difficult to assess and across a small area $\left(10 \mathrm{~km}^{2}\right)$ there could large differences in evapotranspiration. These differences may occur as a result of increased soil water evaporation from the soil surface when the plants are small because of the exposed soil. These differences caused by differential rainfall would be expected to diminish as the crop canopy develops because the amount of exposed soil would decrease and evapotranspiration would be dominated by transpiration from the canopy.

The third factor which caused a difference in the spatial variation in evapotranspiration is related to the soil water holding capacity as shown in Table 1. Across the different sites for the experiment in 2002, Hatfield et al. (2007) observed differences among sites as shown in Figs. 7 and 8 . These differences were large for the short-term observations in this study.

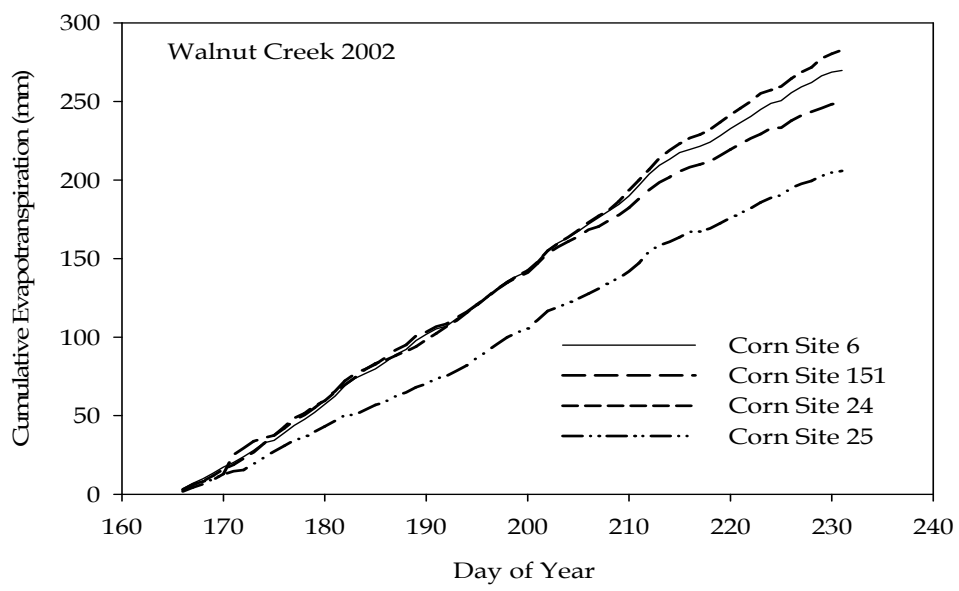

Fig. 7. Cumulative evapotranspiration across four corn fields with detailed measurements in Walnut Creek watershed in 2002.

These observations reveal important components of factors which induce spatial variation in evapotranspiration. For the four corn fields, there was a significant difference in the cumulative evapotranspiration for field 25 compared to the other fields (Fig. 7). In addition to the measurements being made in the soil with a lower water holding capacity, this field also had less rainfall during this portion of the growing season. These differences occurred early in the season and persisted throughout the period of measurements. This is in contrast to the other three fields in which there were similar evapotranspiration values until late in the growing season in which soil water holding capacity became the dominant factor. This 
degree of differential response would be expected if the energy input and rainfall amounts were the same but the storage factor changed.

In the soybean fields, there was little difference in the early season evapotranspiration among field and the differences among fields began to appear when the growth of the plant achieved full cover and water use rates were at their peak (Fig. 8). Separation among the fields was due to the soil water holding capacity of the field in which measurements were being made. The differences among fields were as large as $25-30 \mathrm{~mm}$ which is significant in terms of crop water use requirements and crop growth.

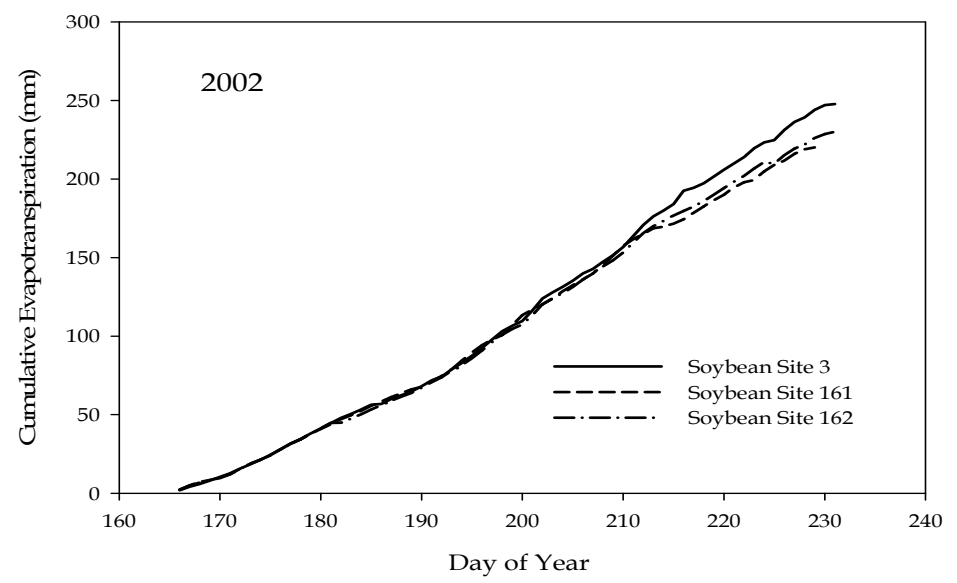

Fig. 8. Cumulative evapotranspiration across four soybean fields with detailed measurements in Walnut Creek watershed in 2002.

In both the corn and soybean observations, there are some notes of caution in terms of understanding spatial and temporal variation in evapotranspiration. Spatial variation of evapotranspiration is a result of a combination of factors and care must be exercised in the placement of energy balance and evapotranspiration equipment within fields and across landscapes in order to capture information from sites representative of the area. These differences can be controlled; however, rainfall patterns and cumulus cloud formation on the shorter time intervals cannot be controlled but should be measured to ensure proper comparisons among sites can be conducted. Overall, the spatial variation in evapotranspiration is due to a complex set of interactions affected the evapotranspiration at a given site. One of the overlooked factors is the soil water holding capacity and the depth of the water extraction caused by differences in rooting depth. These are often considered to be small; however, in our observations these factors can account for 100-200 $\mathrm{mm}$ of seasonal water use differences among sites. These differences coupled with spatial variation in rainfall during the growing season can lead to even greater differences among 
sites. In temperate regions, the spatial pattern of rainfall is a random event while the spatial variation in soil characteristics is a fixed position on the landscape causing the exact seasonal pattern of evapotranspiration for a given year to be a combination of the soil and weather patterns. Understanding the factors causing spatial variation in evapotranspiration will lead to improved capabilities for water management in cropping systems.

\section{References}

Eichinger, W.E., Cooper, D.I., Hipps, L.E., Kustas, W.P., Neale, C.M.N. \& Prueger, J.H. (2006). Spatial and temporal variation in evapotranspiration using Raman lidar. Adv. Water Res. 29: 369-381.

Farmer, D., Sivapalan, M. \& Jothityangkoon, C. (2003). Climate, soil, and vegetation controls upon the variability of water balance in temperate and semiarid landscapes. Water Resource Res. 39:1035, doi:10.1029/2001WR00003238.

Hatfield, J.L., Prueger, J.H. \& Kustas, W.P. (2007). Spatial and temporal variation of energy and carbon fluxes in Central Iowa. Agron. J. 99:285-296.

Hatfield J.L., Jaynes, D.B., Burkart, M.R., Cambardella, C.A., Moorman, T.B., Prueger, J.H. \& Smith, M.A. (1999). Water Quality in Walnut Creek Watershed: Setting and Farming Practices. J. Environ. Qual. 28:11-24.

Hernandez-Ramirez, G., Hatfield, J.L., Parkin, T.B., Prueger, J.H. \& Sauer, T. J. (2010). Energy balance and turbulent flux partitioning in a corn-soybean rotation in the Midwestern U.S. Theor. Appl. Climatol. 100:79-92.

Kustas, W.P. \& Albertson, J.D. (2003). Effects of surface temperature on land atmosphere exchange: A case study from Monsoon 90. Water Resource Res. 39:1159, doi:10.1029/2001WR001226.

Kustas, W.P., Hatfield, J.L. \& Prueger, J.H. (2005). The Soil Moisture Atmosphere Coupling Experiment (SMACEX): Background, Hydrometeorological Conditions and Preliminary Findings. J. Hydrometeorol. 6:791-804.

Kustas, W.P., Prueger, J.H., Hatfield, J.L., MacPherson,J.I., Wolde, M., Neale, C.M.U., Eichinger, W.E., Cooper, D.I., Norman, J.M. \& Anderson, M. (2003). An overview of the Soil-Moisture-Atmospheric-Coupling-Experiment (SMACEX) in central Iowa. American Meteorological Society, 17th Conference on Hydrology, Long Beach, CA Feb. 09-12, pp 1-5.

Li, Z.Q., Yu, G.R., Li, Q.K., Fu, Y.L \& Li, Y.N. (2006). Effect of spatial variation on areal evapotranspiration in Haibei, Tiber plateau, China. Int J. Remote Sens. 27:34873498.

Mo, X.G., Liu, S.X., Lin, Z.H. \& Zhao, W.M. (2004). Simulating temporal and spatial variation in evapotranspiration over the Lushi Basin. J. Hydrology. 285:125-142.

Zhang, S.W., Yei, Y.P., Li, H.J. \& Wang, Z. (2010). Temporal-spatial variation in crop evapotranspiration in Hebei Plain, China. J. Food Agric. Environ. 8:672-677.

Zhang, X.Q., Ren, Y., Yin, Z.Y., Lin, Z.Y, \& Zheng, D. (2009). Spatial and temporal variation patterns of reference evapotranspiration across the Qingahi-Tibetan Plateau during 1971-2004. J Geophysical Res. Atmos. 114: D15105. 
Zhang, X.T., Kang, S.K., Zhang, L. \& Liu, J.Q. (2010). Spatial variation of climatology monthly crop reference evapotranspiration and sensitivity coefficients in Shiyang river basin of northwest China. Agric. Water Mgt. 97:1506-1510. 


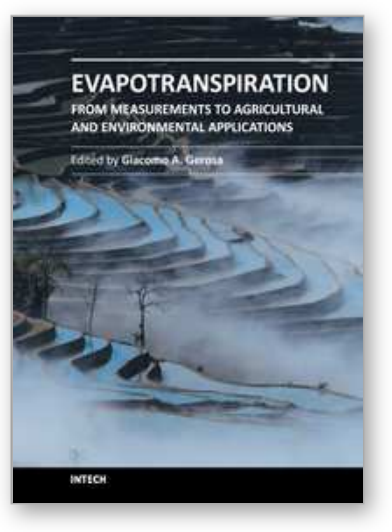

\section{Evapotranspiration - From Measurements to Agricultural and Environmental Applications}

Edited by Dr. Giacomo Gerosa

ISBN 978-953-307-512-9

Hard cover, 410 pages

Publisher InTech

Published online 09, November, 2011

Published in print edition November, 2011

This book represents an overview of the direct measurement techniques of evapotranspiration with related applications to the water use optimization in the agricultural practice and to the ecosystems study. Different measuring techniques at leaf level (porometry), plant-level (sap-flow, lysimetry) and agro-ecosystem level (Surface Renewal, Eddy Covariance, Multi layer BREB), are presented with detailed explanations and examples. For the optimization of the water use in agriculture, detailed measurements on transpiration demands of crops and different cultivars, as well as results of different irrigation schemes and techniques (i.e. subsurface drip) in semi-arid areas for open-field, greenhouse and potted grown plants are presented. Aspects on ET of crops in saline environments, effects of ET on groundwater quality in xeric environments as well as the application of ET to climatic classification are also depicted. The book provides an excellent overview for both, researchers and student,s who intend to address these issues.

\section{How to reference}

In order to correctly reference this scholarly work, feel free to copy and paste the following:

Jerry L. Hatfield and John H. Prueger (2011). Spatial and Temporal Variation in Evapotranspiration, Evapotranspiration - From Measurements to Agricultural and Environmental Applications, Dr. Giacomo Gerosa (Ed.), ISBN: 978-953-307-512-9, InTech, Available from:

http://www.intechopen.com/books/evapotranspiration-from-measurements-to-agricultural-and-environmentalapplications/spatial-and-temporal-variation-in-evapotranspiration

\section{INTECH}

open science | open minds

\section{InTech Europe}

University Campus STeP Ri

Slavka Krautzeka 83/A

51000 Rijeka, Croatia

Phone: +385 (51) 770447

Fax: +385 (51) 686166

www.intechopen.com

\section{InTech China}

Unit 405, Office Block, Hotel Equatorial Shanghai

No.65, Yan An Road (West), Shanghai, 200040, China

中国上海市延安西路65号上海国际贵都大饭店办公楼 405 单元

Phone: +86-21-62489820

Fax: $+86-21-62489821$ 
(C) 2011 The Author(s). Licensee IntechOpen. This is an open access article distributed under the terms of the Creative Commons Attribution 3.0 License, which permits unrestricted use, distribution, and reproduction in any medium, provided the original work is properly cited. 